\title{
Identification of Anticoagulant Activities in Salivary Gland Extracts of Four Horsefly Species (Diptera, Tabanidae)
}

\author{
M. Kazimírováa M. Šulanováb $\quad$ M. Kozánek ${ }^{a} \quad$ P. Takáča \\ M. Labuda a P.A. Nuttallc \\ a Institute of Zoology, Slovak Academy of Sciences and bepartment of Animal Physiology \\ and Etology, Faculty of Natural Sciences, Comenius University, Bratislava, Slovakia; \\ 'Centre for Ecology and Hydrology, NERC, Oxford, UK
}

\section{Key Words}

Tabanidae · Arthropods · Anticoagulant • Thrombin inhibition

\begin{abstract}
Anticoagulant activities against the extrinsic and intrinsic coagulation pathways were identified in salivary gland extracts (SGE) prepared from four tabanids (Hybomitra muehlfeldi, Tabanus autumnalis, Haematopota pluvialis, Heptatoma pellucens). All extracts prolonged human plasma clotting time in a dose-dependent manner and inhibited thrombin activity in the chromogenic substrate assay. Horsefly SGE did not inhibit factor $\mathrm{Xa}$. Partial purification of SGE proteins using reversed-phase high-performance liquid chromatography revealed species-specific differences in the elution profiles and range of fractions with anticoagulant activities.
\end{abstract}

Copyright $@ 2002$ S. Karger AG, Basel

\begin{tabular}{ll}
\hline KARGER & ( 2002 S. Karger AG, Basel \\
Fax +4161306 1234 & 0301-0147/01/0316-0294\$17.50/0 \\
$\begin{array}{l}\text { E-Mail karger@karger.ch } \\
\text { www.karger.com }\end{array}$ & $\begin{array}{l}\text { Accessible online at: } \\
\text { www.karger.com/journals/hae }\end{array}$
\end{tabular}

\section{Introduction}

Haematophagous arthropods have major health and economic impacts on humans and animals. To facilitate blood feeding, such arthropods produce a wide array of antihaemostatic compounds in their salivary glands which they secrete into the skin feeding site via their saliva. These substances developed during the evolution of the ectoparasite-host relationship and serve to overcome haemostatic mechanisms and immune reactions of the host [1-3]. Studies on the activity, mode of action and characteristics of these compounds have been carried out more extensively during the last decade and were driven by their potential therapeutic use in treatment of defects in haemostasis and diseases of the cardiovascular and immune systems.

Antihaemostatic compounds of bloodsucking arthropods have been distinguished into several groups such as inhibitors of fac-

\footnotetext{
Dr. Mária Kazimírová

Institute of Zoology, Slovak Academy of Sciences

SK-84206 Bratislava (Slovakia)

Tel. +4212 59302645 , Fax +421 259302646
}

E-Mail uzaemkaz@savba.sk 
tors VII and V, thrombin (antithrombins), the prothrombinase complex (mainly inhibitors of factor Xa), platelet functions and fibrinolytic enzymes [1, 3, 4]. Most haematophagous arthropods have been found to produce several different anticoagulants each inhibiting different factors of the coagulation pathways. The majority of anticoagulants isolated from arthropods have been peptides and small proteins.

There have been comparatively few studies on antihaemostatic factors produced by tabanids (horseflies, clegs and deerflies). Prior to feeding, tabanids make an incision in the skin of the host and feed on the blood that wells up [5]. Females of the larger species are able to ingest up to $200 \mathrm{mg}$ of blood within only 1-3 min [6], suggesting that they must possess very potent anticlotting mechanisms. Potent anticoagulant activity was discovered in the salivary glands of some representatives of the Tabaninae subfamily, which was attributed to antithrombin [7]. A thrombin inhibitor, isolated from Tabanus bovinus, was named tabanin [8]. Tabanin is thought to be an approximately $7-\mathrm{kD}$ peptide [4]; however, its amino acid sequence is unknown. In addition to tabanin, a platelet aggregation inhibitor and a potent glycoprotein IIb/IIIa fibrinogen receptor antagonist have been isolated from deerflies, Chrysops sp. of the Chrysopsinae subfamily $[9,10]$.

We report identification of anticoagulation activities in crude and partially purified salivary gland extracts from four horsefly species from the Tabaninae subfamily.

\section{Material and Methods}

Salivary Gland Extracts

Female tabanids were collected using Manitobatype traps with carbon dioxide as the attractant at selected sites in SW Slovakia during May-September 1999-2000. The flies were transported to the laborato- ry and immediately processed. Females were immobilized on ice and salivary glands (SG) were dissected under a stereomicroscope in PBS pH 7.2 (0.01 $\mathrm{M}$ phosphate buffer, $0.15 \mathrm{M} \mathrm{NaCl}$ ). Dissected SGs were transferred to Eppendorf tubes and stored in PBS at $-70^{\circ} \mathrm{C}$. Prior to coagulation assays, SGs were homogenized and centrifuged in a bench-top centrifuge at 10,000 $\mathrm{rpm}$ for $15 \mathrm{~min}$. This procedure was repeated twice. Supernatants were pooled and referred to as salivary gland extracts (SGE). Serial dilutions of SGE were tested in coagulation assays.

\section{$R P-H P L C$}

For partial purification and identification of anticoagulant compounds, SGE of the species Hybomitra muehlfeldi (173 SG pairs), Tabanus autumnalis (63 SG pairs), Heptatoma pellucens (50 SG pairs) and Haematopota pluvialis (355 SG pairs) were used.

SG samples stored at $-70^{\circ} \mathrm{C}$ in PBS were incubated in a water bath at approximately $90^{\circ} \mathrm{C}$ for $5 \mathrm{~min}$, homogenized and centrifuged in a bench-top microcentrifuge at $10,000 \mathrm{rpm}$ for $15 \mathrm{~min}$. The supernatants (crude SGE) were filtered through a Millex-LG syringe driven filter unit $(0.20 \mu \mathrm{m}, 4 \mathrm{~mm})$. Filtered SGE was further processed by HPLC.

The SGE samples were diluted in $500 \mu \mathrm{l}$ of $10 \%$ acetonitrile $(\mathrm{ACN})$ with $0.1 \%$ trifluoroacetic acid (TFA) (buffer A) and loaded onto a Beckman Instruments 126/168 DAD HPLC system. SGE were applied to a Vydac C-4, $250 \times 4.6 \mathrm{~mm}$ ID, $5-\mu \mathrm{m}$ particle size column. Proteins were eluted with a gradient of ACN $(10-100 \%)$ in $0.1 \%$ TFA at a flow rate of $1 \mathrm{ml} / \mathrm{min}$ and $1 \%$ increments of $\mathrm{ACN} / \mathrm{min}$. Peaks were detected at UV 210 and $220 \mathrm{~nm}$. Fractions were collected and dried in a Savant Instruments Speed-Vac to a volume of approximately $50 \mu 1$.

\section{Coagulation Assays}

Pooled human citrated plasma showing normal coagulation times was provided by the Department of Haematology and Transfusion of the Slovak Institute of Cardiovascular Diseases in Bratislava, Slovakia.

Thrombin time (TT, thrombin activity assay), prothrombin time (PT, extrinsic pathway assay) and activated partial thromboplastin time (APTT, intrinsic pathway assay) were used to determine the anticoagulant activities in tabanid SGE and SGE fractions. The assays were carried out with $50 \mu \mathrm{l}$ (PT, APTT) or $100 \mu \mathrm{l}(50 \mu \mathrm{l}$ for HPLC fractions) (TT) plasma. The plasma was pre-incubated with $1-5 \mu \mathrm{l} \mathrm{SGE,} 1 \mu \mathrm{l}$ HPLC fraction or the same volume of PBS, pH 7.2 (control), in a water bath at $37^{\circ} \mathrm{C}$ for $1 \mathrm{~min}$. The reaction was started with the addition of the appropriate pre- 
warmed reagent: $100 \mu \mathrm{l}(50 \mu \mathrm{l}$ for HPLC fractions) Dade Thromboclotin reagent (lyophilized bovine thrombin, 2.5 NIH U/ml, Dade AG, Düdingen, Switzerland) in the TT assay, $100 \mu 1$ Dade Thromboplastin IS reagent (lyophilized thromboplastin from rabbit brain, $1.0 \times 10^{-2} \mathrm{~mol} / 1 \mathrm{Ca}^{2+}$, Dade International Inc., Miami, Fla., USA) in the PT assay, and $50 \mu 1$ Dade Actin FS Activated PTT reagent (purified soy phosphatides in $1.0 \times 10^{-4} \mathrm{M}$ ellagic acid, Dade) $+50 \mu \mathrm{l}$ of pre-warmed $0.02 \mathrm{M} \mathrm{CaCl}_{2}$ after $3 \mathrm{~min}$ of incubation in the APTT assay. The time required for the formation of the fibrin clot was determined in triplicate samples visually using a stopwatch. In all assays, fibrin clot formation was monitored for a maximum of $2 \mathrm{~min}$. If no clot formation occurred by that time, SGE or fraction was considered to inhibit coagulation by $100 \%$. Prolongation of coagulation in comparison with the control was expressed as percentage of inhibition in the range $0-100 \%$.

\section{Chromogenic Substrate Assays for Thrombin and} Factor Xa

The assays were carried out using 96-well microplates. For screening of antithrombin activity, $190 \mu \mathrm{l}$ Tris buffer $(50 \mathrm{~m} M$ Tris, $227 \mathrm{~m} M \mathrm{NaCl}$, pH 8.3, containing $0.1 \%$ BSA and $0.1 \%$ sodium azide), $10 \mu \mathrm{l}$ Tris buffer containing $0.029 \mathrm{NIH}$ units of thrombin from human plasma (Sigma, Steinheim, Germany), $10 \mu \mathrm{l}$ PBS (control), $10 \mu \mathrm{l}$ of SGE (6 $\mu \mathrm{g}$ protein), or $2 \mu \mathrm{l}$ $(<0.1 \mu \mathrm{g}$ protein) of HPLC fractions $+8 \mu \mathrm{l}$ PBS were pipetted into a well and incubated at room temperature (RT) for $10 \mathrm{~min}$. Twenty microliters of substrate, $1.9 \mathrm{~m} M \mathrm{~N}$ - -tosyl-gly-pro-arg- $p$-nitroanilide (Sigma), dissolved in redistilled water were added. For screening of anti-factor Xa activity, $190 \mu \mathrm{l}$ Tris buffer (50 $\mathrm{m} M$ Tris, $150 \mathrm{~m} M \mathrm{NaCl}$, pH 8.3 , containing $0.1 \%$ BSA and $0.1 \%$ sodium azide), $20 \mu \mathrm{l}$ Tris buffer containing 0.05 NIH units of factor Xa from bovine plasma (Sigma) and $10 \mu 1$ PBS (control) or $10 \mu 1$ of SGE ( $6 \mu \mathrm{g}$ protein) were pipetted into a well and incubated at RT for $10 \mathrm{~min}$. Twenty microliters of substrate, 2 $\mathrm{m} M$ Chromozym X (Boehringer, Mannheim, Germany), dissolved in redistilled water were then added. After addition of the substrates, changes in absorbance were monitored in two parallel samples at $405 \mathrm{~nm}$ for 30 min using an ELISA reader (Multiskan RC, Labsystems, Helsinki, Finland). The results are expressed as progress curves showing substrate hydrolysis by thrombin or factor $\mathrm{Xa}$ (i.e. changes in absorbance at $405 \mathrm{~nm}$ dependent on time, means of two replicates).

\section{Protein Assays}

Protein concentrations were determined for SGE and SGE fractions by the method of Bradford [11], adapted to 96-well microplates. Bovine serum albumin was used as standard. Absorbance was read by an ELISA reader (Multiskan RC, Labsystems) at $595 \mathrm{~nm}$.

\section{Statistics}

Statistical analyses were performed using Statgraphics, version V software (Statistical Graphics Corporation, Rockville, Md., USA). For statistical analysis, percentages were transformed to arcsine. Two-factor analysis of variance (ANOVA), followed by Tukey's test was used.

\section{Results}

\section{Anticoagulant Activities in Horsefly SGE}

Anticoagulant activities against thrombin and the extrinsic and intrinsic coagulation pathways were found in horsefly SGE in the TT, PT and APTT assays, respectively (fig. 1). All extracts prolonged human plasma clotting time in a dose-dependent manner. Comparison of the four species showed significant differences in the anticlotting activities of their SGE. The strongest anticoagulant activity in all assays was exhibited by $H$. pellucens, and the weakest by $H$. pluvialis. Salivary anticlotting activity of $H$. pluvialis was significantly less in both the TT and PT assay, while in the APTT assay differences were significant between all examined species $(\mathrm{p}<0.001$, Tukey's test).

Based on comparisons of the salivary anticlotting activity of the four tabanids investigated in this study by two-way ANOVA, followed by Tukey's test, considering species and dilution as factors, the species were ranked $H$. pellucens $>T$. autumnalis $>H$. muehlfeldi $>$ $H$. pluvialis $\left(\mathrm{F}_{\text {species }}=22.71^{* * *}, \mathrm{~F}_{\text {dilution }}=\right.$ $\left.26.92^{* * *}, \mathrm{p}<0.001\right)$. The differences were significant between the first three species and $H$. pluvialis and between $H$. pellucens and $H$. muehlfeldi. 
Fig. 1. Effect of salivary gland extracts of $H$. muehlfeldi, T. autumnalis, $H$. pluvialis and $H$. pellucens on inhibition of fibrin clot formation of human plasma. a TT assay $\left(\mathrm{F}_{\text {species }}=60.79 *, \mathrm{~F}_{\text {dilution }}=\right.$ $\left.66.84^{* * *}\right)$. b PT assay $\left(\mathrm{F}_{\text {species }}=\right.$ $\left.15.13^{* * *}, \quad \mathrm{~F}_{\text {dilution }}=52.97^{* * *}\right)$. c APTT assay $\left(\mathrm{F}_{\text {species }}=62.54 * * *\right.$, $\left.\mathrm{F}_{\text {dilution }}=55.16^{* * *}\right) . \mathrm{F}_{\text {species, }} \mathrm{F}_{\text {dilution }}$ - $F$ ratio for the factor of species and SGE dilution, respectively; $* * * \mathrm{p}<0.001$ (two-way ANOVA). Values represent means \pm SD of three assays. During analysis, percentages were transformed to arcsine. Actual percentages are presented.
వ $H$. muehlfeldi $\square T$. autumnalis $\mathbf{\square}$. pluvialis 目 $H$. pellucens
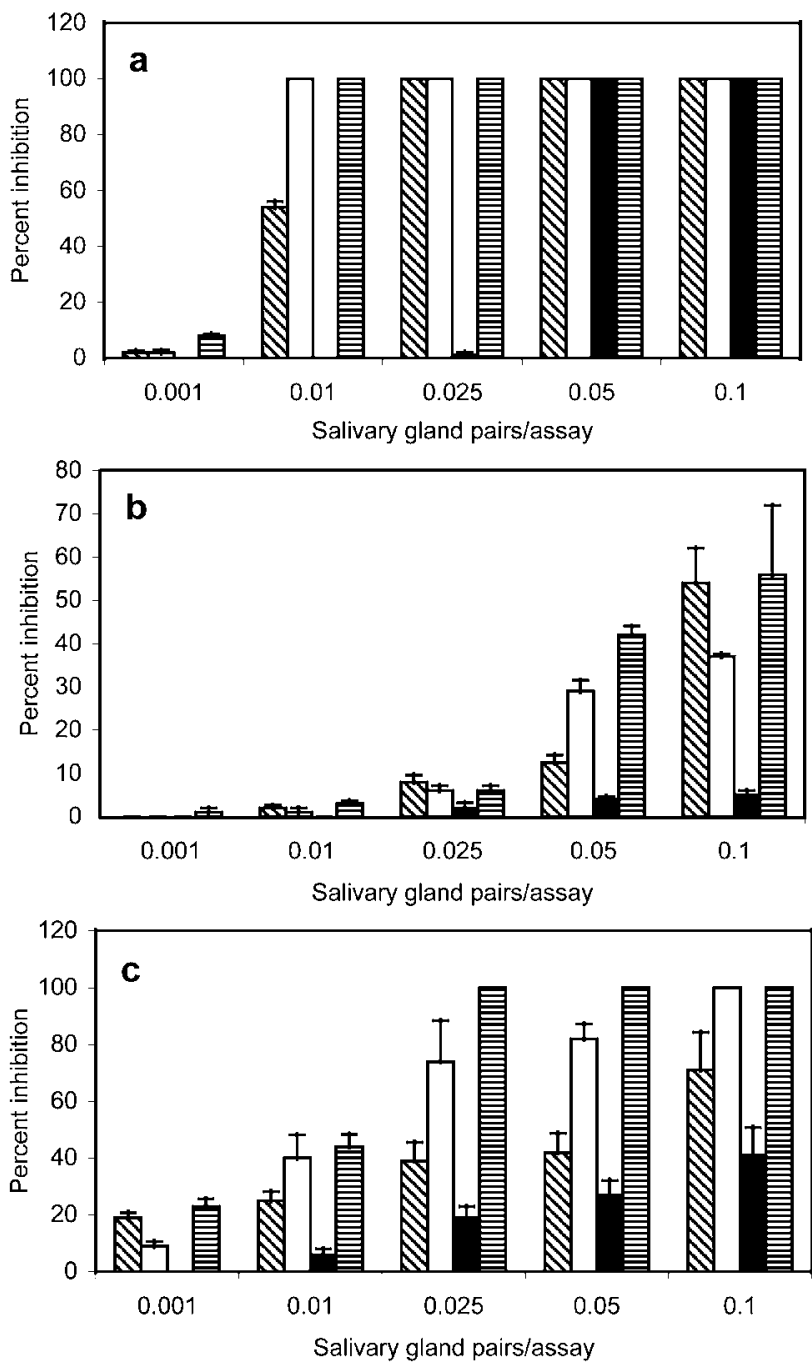

\section{RP-HPLC of Horsefly SGE}

Anticoagulant activities were identified in RP-HPLC fractions for all examined species. For individual species, the chromatograms and anticoagulant activities of fractions in the TT, PT and APTT assays are shown in figures $2-5$. The elution profiles and activity spectrum of fractions were species-specific, although the most potent fractions were those with retention times between 17 and $25 \mathrm{~min}$. The exception was T. autumnalis, for which strong anticoagulation activity was spread across fractions with retention times between 27 and $44 \mathrm{~min}$. Protein concentrations in the fractions were $<0.1 \mu \mathrm{g} / \mu \mathrm{l}$. 


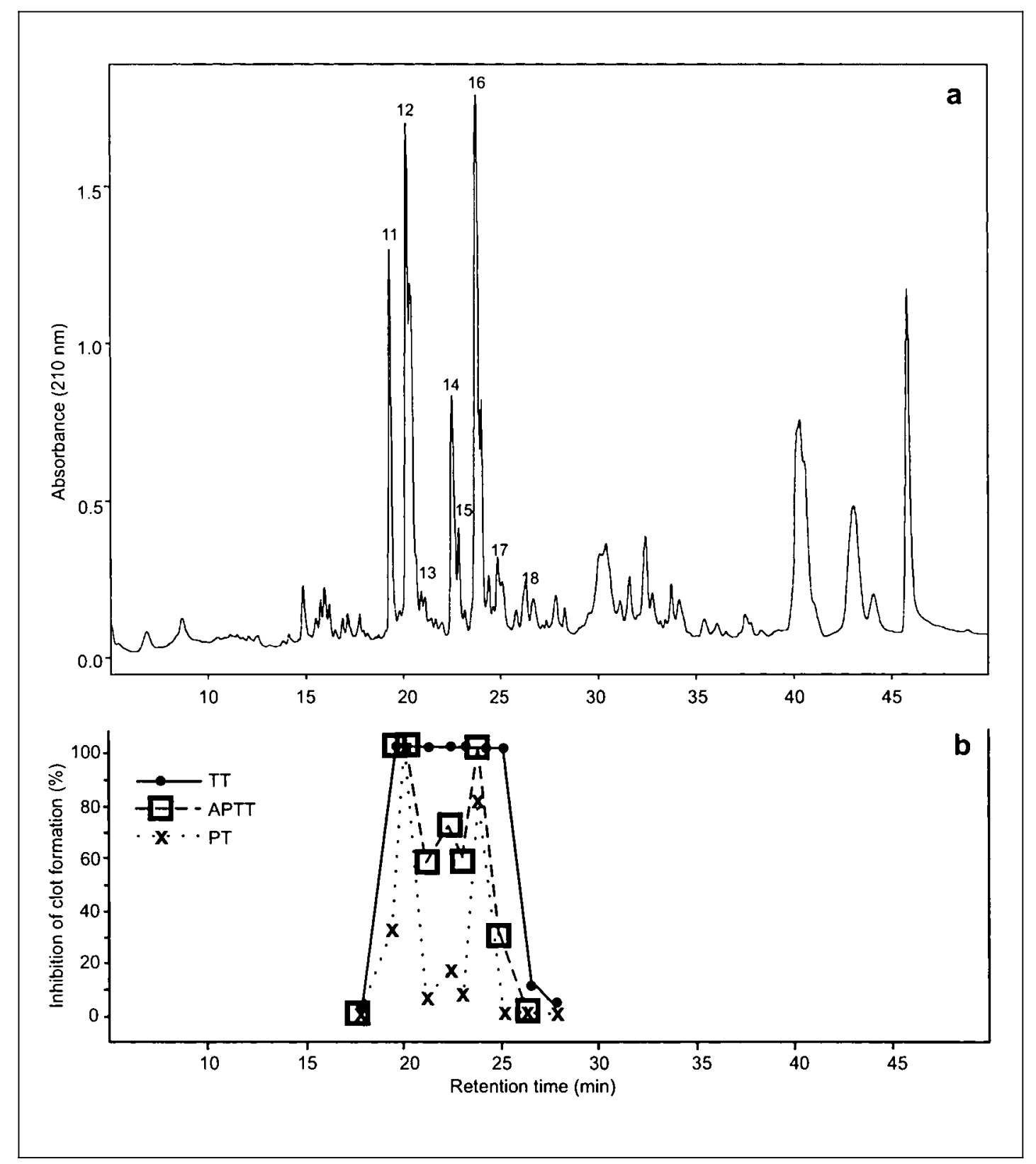

Fig. 2. RP-HPLC of anticoagulant activities in salivary gland extracts from $H$. muehlfeldi. a $173 \mathrm{SG}$ pairs were processed as described in Material and Methods and loaded onto a Vydac C-4 column. The sample was eluted with a linear $10-100 \%$ ACN gradient with $0.1 \%$ TFA at a flow rate of $1 \mathrm{ml} / \mathrm{min}$. Eluted fractions were concentrated to $\sim 50 \mu \mathrm{l}$ in a Speed-Vac. b One microliter of each fraction was used for the coagulation assays. 


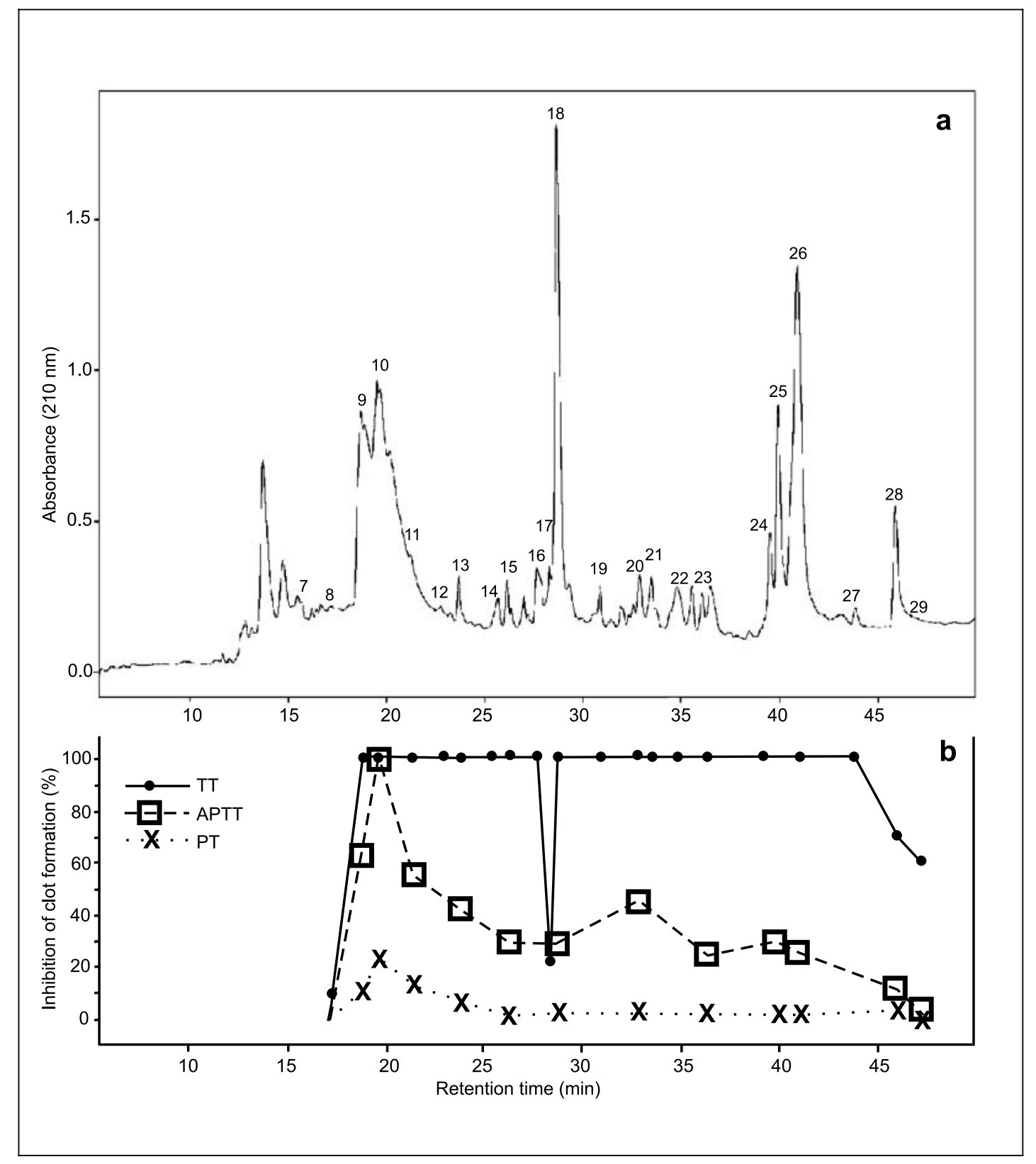

Fig. 3. RP-HPLC of anticoagulant activities in salivary gland extracts from T. autumnalis. a 63 SG pairs were processed as described in Material and Methods and loaded onto a Vydac C-4 column. The sample was eluted with a linear $10-100 \%$ ACN gradient with $0.1 \%$ TFA at a flow rate of $1 \mathrm{ml} / \mathrm{min}$. Eluted fractions were concentrated to $\sim 50 \mu \mathrm{l}$ in a Speed-Vac. b One microliter of each fraction was used for the coagulation assays. 


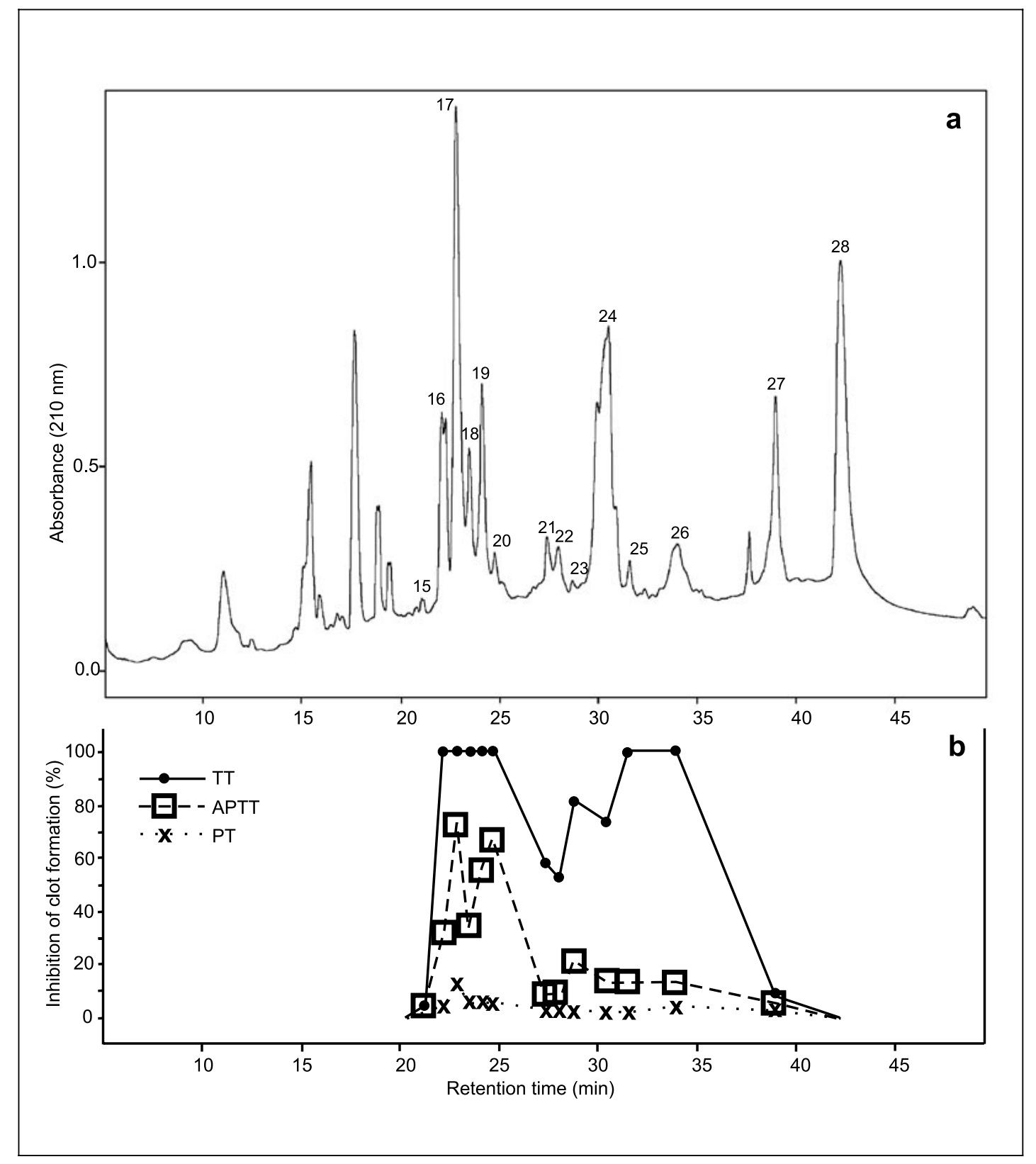

Fig. 4. RP-HPLC of anticoagulant activities in salivary gland extracts from $H$. pluvialis. a 355 SG pairs were processed as described in Material and Methods and loaded onto a Vydac C-4 column. The sample was eluted with a linear $10-100 \%$ ACN gradient with $0.1 \%$ TFA at a flow rate of $1 \mathrm{ml} / \mathrm{min}$. Eluted fractions were concentrated to $\sim 50 \mu \mathrm{l}$ in a Speed-Vac. b One microliter of each fraction was used for the coagulation assays. 


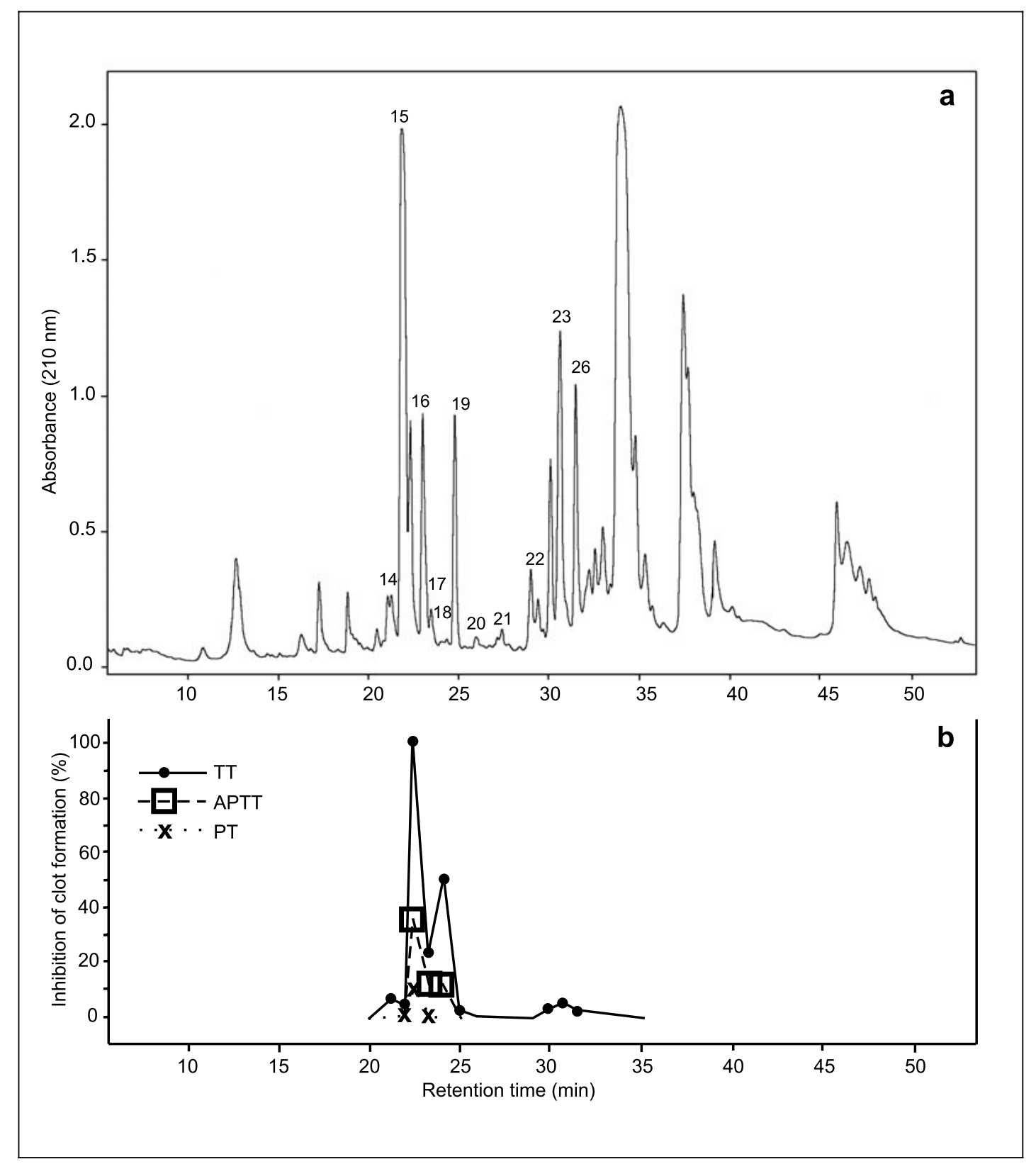

Fig. 5. RP-HPLC of anticoagulant activities in salivary gland extracts from $H$. pellucens. a 50 SG pairs were processed as described in Material and Methods and loaded onto a Vydac C-4 column. The sample was eluted with a linear $10-100 \%$ ACN gradient with $0.1 \%$ TFA at a flow rate of $1 \mathrm{ml} / \mathrm{min}$. Eluted fractions were concentrated to $\sim 50 \mu \mathrm{l}$ in a Speed-Vac. b One microliter of each fraction was used for the coagulation assays. 


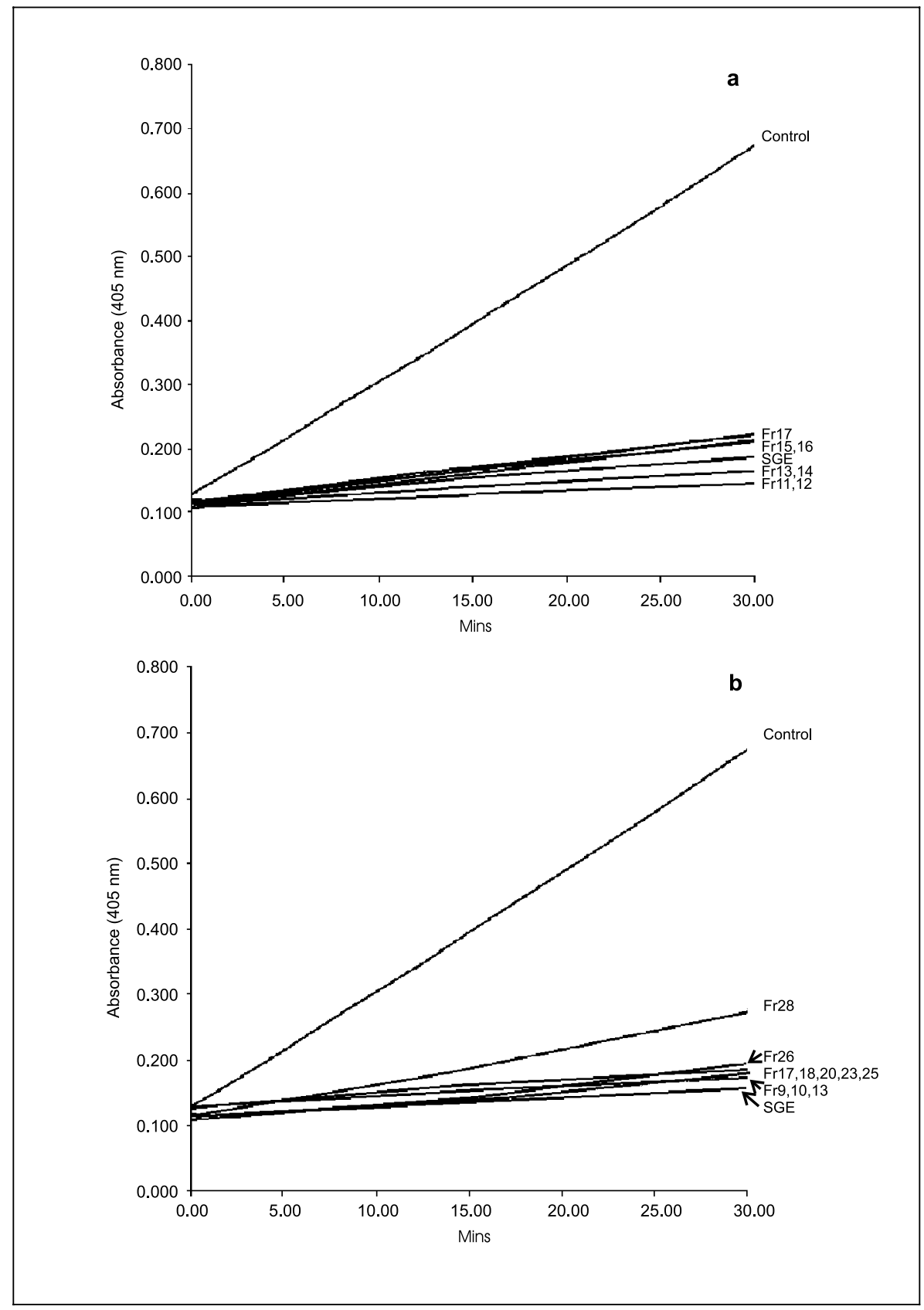

Fig. 6. Inhibitory effect of horsefly salivary gland extracts and fractions on substrate hydrolysis by thrombin (human thrombin $-0.029 \mathrm{U} /$ well, substrate -20 mM Tosyl-glycyl-prolyl-arginine-4-nitroanilideacetate $-20 \mu \mathrm{l} / \mathrm{wel})$. Control - $10 \mu \mathrm{l}$ PBS, SGE ( $\sim 6 \mu \mathrm{g}$ protein in $10 \mu \mathrm{l} \mathrm{PBS} /$ well), Fr - HPLC fractions
$(<0.1 \mu \mathrm{g}$ protein in $2 \mu \mathrm{l}$ fraction diluted to $10 \mu \mathrm{l}$ in $\mathrm{PBS} /$ well). For the numbering of fractions, see the corresponding chromatograms in figures 2-5. a $H$. muehlfeldi. b T. autumnalis. c $H$. pluvialis. d $H$. pellucens. 


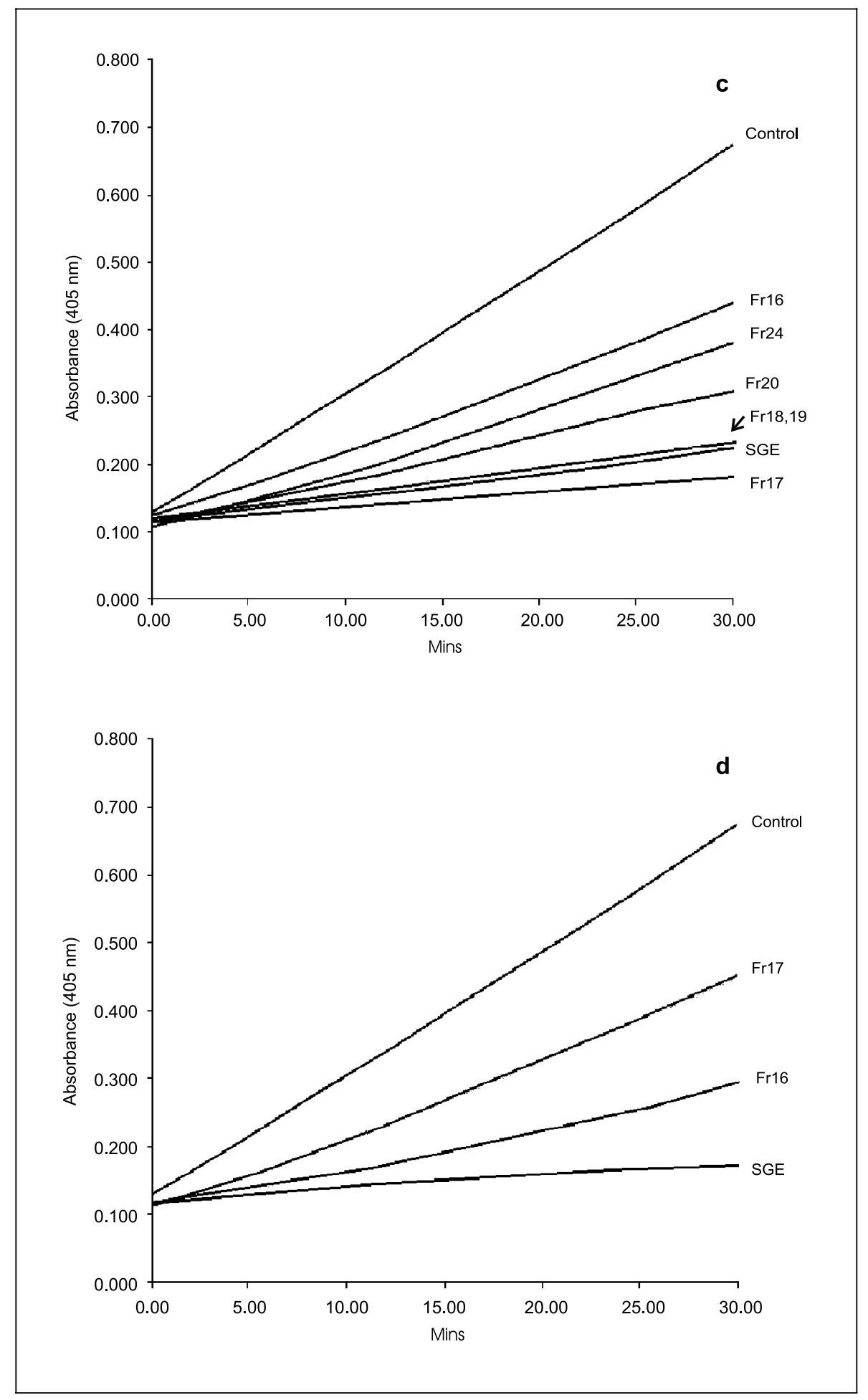

Anticoagulants in Horsefly Salivary

Haemostasis 2001;31:294-305

303 Glands 


\section{Chromogenic Substrate Assay}

Incubation of bovine factor Xa with its chromogenic substrate Chromozym $\mathrm{X}$ resulted in an increase in absorbance at $405 \mathrm{~nm}$. The reaction was not inhibited by any of the tabanid SGE and progress curves of substrate hydrolysis were similar to the control (progress curves not shown).

Chromogenic substrate assay for human thrombin activity showed inhibition of substrate hydrolysis by SGE of all investigated species (fig. 6). The presence of compounds with antithrombin activity was also confirmed in HPLC fractions (fig. 6).

\section{Discussion}

Haematophagous arthropods possess various antihaemostatics in their saliva to overcome host haemostatic systems. Most of the compounds identified so far are direct inhibitors of coagulation factors (mainly antithrombins and inhibitors of factor Xa), or they inhibit platelet aggregation or act as vasodilators $[2,12]$. In Diptera, inhibition of thrombin and factor Xa seems to be the most common mode of action of anticoagulants [3, 12]. The strategy of tabanids to counteract host haemostasis might be similar to other pool feeders (e.g. black flies, ticks, leeches) and probably differs from other higher Diptera.

Black flies show activities against factor $\mathrm{Xa}$ [13], thrombin [14, 15], factor V [16], platelet aggregation mediated by apyrase [17] and vasodilation [18]. In tabanids at least two anticoagulation strategies seem to be present, based on: (1) potent antithrombins in species of the genera Tabanus, Hybomitra, Haematopota and Heptatoma [8, this paper]; (2) inhibition of platelet aggregation by deerflies (Chrysops spp.) $[9,10]$. Apart from the discovery of tabanin, a potent inhibitor of thrombin $[4,7$, 8] in one of the largest species (Tabanus bovinus) which shows similarities to the mode of action of hirudin, horsefly anticoagulants have not been studied. Our results confirmed the existing knowledge on horsefly anticoagulants in routine coagulation assays (TT, PT, APTT). The results of the chromogenic substrate assay suggest that horseflies prevent blood coagulation mainly through the presence of a potent antithrombin, but not through inhibition of factor Xa. Hybomitra spp. and Tabanus spp. SGE also inhibit platelet aggregation induced by collagen and ADP, which is suggested to be a consequence of its strong antithrombin activity [P. Martin, unpubl. results]. Nevertheless, further extensive studies are needed to clarify the mode of action of horsefly anticoagulants.

Partial purification of the anticoagulants from the horsefly SGE by RP-HPLC showed species-specific differences in their activity spectrum. The results suggest that more than one anticoagulant or several isoforms are present. Moreover, horsefly anticoagulants are highly potent at extremely low concentrations. Molecular weights of the peptides in the active fractions could not be detected by electrophoresis, but preliminary studies using mass spectrometry indicate that they are low molecular weight peptides [P. Takáč et al., unpubl. results]. Further purification and amino acid sequence analyses will reveal whether homology exists between horsefly anticoagulants and other naturally occurring thrombin inhibitors.

In conclusion, our study demonstrated interspecific differences in the anticoagulant activities in the SGE of four horsefly species. The mode of action of the anticoagulant(s) is probably based mainly on the inhibition of thrombin; however, tabanids may target other factors of the coagulation cascade. Horsefly saliva may also offer a source of new compounds for potential pharmaceutical use. 


\section{Acknowledgments}

The authors wish to thank Ľ. Vidlička, F. Čiampor and L. Roller for their help in fieldwork and species identification and Dr. E. Silvanová and Dr. I. Bala- nová from the Slovak Institute of Cardiovascular Diseases in Bratislava for providing plasma samples. The research was financially supported by Evolutec Ltd. and partly by grant VEGA, No. 2/1129/21, from the Slovak Academy of Sciences.

\section{References}

1 Ribeiro JMC: Role of saliva in blood-feeding by arthropods. Annu Rev Entomol 1987;32:463-478.

2 Wikel SK: The immunology of hostectoparasitic arthropod relationships. Wallingford, CAB International, 1996.

3 Arocha-Piñango CL, Marchi R, Carvajal $\mathrm{Z}$, Guerrero B: Invertebrate compounds acting on the hemostatic mechanism. Blood Coagul Fibrinolysis 1999; 10:43-68.

4 Markwardt F: Coagulation inhibitors from animals feeding on blood. Rev Iberoamer Tromb Hemost 1994; 7:225-231.

5 Chvála M, Lyneborg L, Moucha J: The horse flies of Europe (Diptera, Tabanidae). Ent Soc Copenhagen, 1972.

6 Chvála M, Hůrka K, Chalupský J, Knoz J, Minář J, Országh I: Fauna ČSSR, Svazek 22, Krevsající mouchy a stř̌čci - Diptera. Academia Nakl ČSAV, Praha, 1980.

7 Markwardt F, Leberecht E: Untersuchungen über den blutgerinnungshemmenden Wirkstoff der Tabaniden. Naturwissenschaften 1959;46:17-18.
8 Markwardt F, Schulz E: Über den Mechanismus der blutgerinnungshemmenden Wirkung des Tabanins. Naunyn-Schmiedebergs Arch Exp Pathol Pharmakol 1960;238:320 328.

9 Grevelink SA, Youssef DE, Loscalzo J, Lerner EA: Salivary gland extracts from the deerfly contain a potent inhibitor of platelet aggregation. Proc Natl Acad Sci USA 1993 90:9155-9158.

10 Reddy VB, Kounga K, Mariano F, Lerner EA: Chrysoptin is a potent glycoprotein IIb/IIIa fibrinogen receptor antagonist present in salivary gland extracts of the deerfly. J Biol Chem 2000;275:15861-15867.

11 Bradford MM: A rapid and sensitive method for the quantitation of microgram quantities of protein utilizing the principle of protein-dye binding. Anal Biochem 1976;72: 248-254.

12 Beaty BJ, Marquardt WC: The Biology of Disease Vectors. Niwot, University Press of Colorado, 1996.

13 Jacobs JW, Cupp EW, Sardana M, Friedman PA: Isolation and characterization of a coagulation factor $\mathrm{Xa}$ inhibitor from black fly salivary glands. Thromb Haemost 1990;64: 235-238.
14 Abebe M, Cupp MS, Ramberg FB, Cupp EW: Anticoagulant activity in salivary gland extracts of black flies (Diptera: Simuliidae). J Med Entomol 1994;31:908-911.

15 Abebe M, Cupp MS, Champagne D, Cupp EW: Simulidin: A black fly (Simulium vittatum) salivary gland protein with anti-thrombin activity. J Insect Physiol 1995;41:10011006.

16 Abebe M, Ribeiro JMC, Cupp MS, Cupp EW: Novel anticoagulant from salivary glands of Simulium vittatum (Diptera: Simuliidae) inhibits activity of coagulation factor V. J Med Entomol 1996;33:173176.

17 Cupp MS, Cupp EW, Ramberg FB: Salivary gland apyrase in black flies (Simulium vittatum). J Insect Physiol 1993;39:817-821.

18 Cupp MS, Ribeiro JMC, Cupp EW: Vasodilative activity in black fly salivary glands. Am J Trop Med Hyg 1994;50:241-246. 